\title{
Non-esterified Fatty Acids Measurement
}

National Cancer Institute

\section{Source}

National Cancer Institute. Non-esterified Fatty Acids Measurement. NCI Thesaurus.

Code C80200.

The determination of the amount of free non-esterified fatty acids present in a sample. 